\title{
REGIONÁLNÍ MUZEUM JAKO KOMUNITNÍ CENTRUM. SMYSL "MALÝCH" MUZEÍ V 21. STOLETÍ
}

PETR BERÁNEK

https://doi.org/10.5817/MuB2019-2-4

Tradice regionálních muzeí v českých zemích sahá až do druhé poloviny 19. století. Jejich primárním posláním bylo uchovávat kolektivní pamět ${ }^{1}$ a poučovat o ní danou komunitu. Tehdy aktuální formy pro sdílení paměti věcí $\mathrm{v}$ různém stupni zachování přetrvaly ještě přes 20. století. V současnosti ovšem tento konzervativní príistup naráží na to, že ve společnosti doby postfaktické nedokáže zcela naplňovat svoji roli garanta kolektivní paměti. ${ }^{2}$ Lze vůbec nalézt přijatelné metody pro sdílení kolektivní paměti v malém muzeu v České republice? Lze připravit jedno univerzální schéma, které by fungovalo $\mathrm{v}$ muzeích malého formátu? Regionální muzea in situ neztratila své poslání uchovat kolektivní pamět, musí si však přehodnotit svůj vztah ke komunitě a jejím současným potřebám a zvyklostem.

$\mathrm{V}$ prvé řadě je nutné definovat oba základní termíny: regionální muzeum a komunita. O vymezení malého muzea $\mathrm{v}$ českém prostředí

1 Problematiku termínu kolektivní, nebo historické, paměti shrnují ŠUBRT, Jiří a Štěpánka PFEIFEROVÁ. Kolektivní pamět jako předmět historicko-sociologického bádání. Historická sociologie, 2010, roč. 2, č. 1, s. 9-29. Pro účel této stati využívám termín kolektivní paměti, jak jej definovali Jan Assman a Maurice Halbwachs. Dle nich je kolektivní pamět soubor vnějších sociálních a kulturních rámců, z nichž jednu část tvoří právě tzv. pamět věcí.

2 Tato problematika „slonových věží, jak například popisuje Jocelyn Dodd, se dotýká celého okcidentálního světa, nikoliv jen středoevropského prostoru. DODD, Jocelyn. The socially purposeful museum. Museologica Brunensia, 2015, roč. 4, č. 2, s. 28-32. O hledání cest, jak muzeu vrátit smysl, svědčí i snaha definovat muzeum právě s ohledem ke vztahu ke komunitě. Take part in creating a new museum definition - the backbone of ICOM. In ICOM [online]. [cit. 2019-05-05]. Dostupný z www: <https://icom.museum/en/activities/ standards-guidelines/museum-definition/>. se pokusil v poslední době Jiří Žalman, který považuje za základní kritérium počet zaměstnanců s podmínkou naplňování účelu muzea ve smyslu zákona $122 / 2000 \mathrm{Sb}^{3}$ Žalmanovu úvahu lze využít jako východisko a je nezbytné, jak připomíná, pohlížet na muzeum jako na jednotku vnímanou z pozice veřejnosti. Jinými slovy, je nutné do ní zahrnout i pobočky velkých muzeí, které daná komunita chápe jako „samostatné“ muzeum. V českém prostředí lze tedy definovat regionální muzeum skrze tři kritéria. Muzejní jednotka splňuje aspoň částečně legislativní vymezení muzea, tj. spravuje registrovanou sbírku, nebo její část, zároveň má maximální počet zaměstnanců do deseti osob. K tomu přistupuje ještě charakteristika spravované sbírky, která až na výjimky zahrnuje předměty z místa sídla, případně $\mathrm{z}$ regionu s přirozenou spádovostí. Do kategorie regionálního muzea tak spadá přibližně $40 \%$ českých muzeí a muzejních poboček. ${ }^{4}$

Vymezení pojmu regionální muzeum usnadňuje obsah termínu komunita. Fakticky zahrnuje takzvanou sídelní komunitu. Lze ji

\footnotetext{
3 ŽALMAN, Jiří. Malá muzea (přednáška na semináři v Plzni). Věstník Asociace muzeí a galerií České republiky, 2007, č. 2, s. 8-10. Pomocí stejného principu definuje malé muzeum i Asociace muzeí a galerií České republiky (dále AMG ČR).

4 Zmíněná definice zahrnuje fakticky tzv. muzea IV. kategorie dle metodiky AMG ČR a pobočky velkých institucí s výjimkou malých specializovaných institucí s nadregionálním významem (např́íklad specializované památníky celorepublikového dosahu). Cf. ŽALMAN, Jiří. Malá muzea (přednáška na semináři v Plzni). Věstník Asociace muzeí a galerí České republiky, 2007, č. 2, s. 8; Projekt „Malá muzea" v rámci AMG. In Asociace muzeí a galerií $\breve{C} R$ [online]. [cit. 2019-05-05]. Dostupný z www: $<$ https://www.cz-museums.cz/web/deni_v_oboru/ mala-muzea/projekt-mala-muzea $>$.
}

tedy primárně definovat jako společenství jedinců $s$ jejich vzájemnými přirozenými vazbami a hierarchií v místě sídla regionálního muzea, či v přirozené spádové oblasti muzea. Z definice regionálního muzea opět vyplývá, že se jedná o komunity $\mathrm{v}$ jednotlivých obcích, menších městech $s$ jejich přirozeným okolím bez ohledu na jejich lokaci vůči velkým aglomeracím. Termín komunita by se neměl vymezovat pouze lokalitou, ale i vlastním smyslem. McMillan a Chavis určují čtyři typické prvky komunity: pocit př́slušnosti a provázanosti s dalšími, pocit vlivu jedince na komunitu a opačně, pocit odměny za př́islušnost ke komunitě a identifikace s její tradicí a historií. ${ }^{5}$ Regionální muzeum, jako zhmotnění části kolektivní paměti, pak přirozeně cílí na všechny čtyři hlediska, byt s různým důrazem. Jeho cílem zůstává především předat pocit příslušnosti a identifikaci s tradicí sídelní komunity.

Právě zevrubná znalost komunity, zejména struktury, návyků a její demografické skladby, patří mezi nezbytné předpoklady pro úspěch regionálního muzea. Struktura i potřeby komunity jsou nicméně natolik individuální a závislé na dané lokalitě včetně jejích vazeb na okolní aglomerace a př́rodní podmínky, že není možné určit jeden závazný model. Např́ílad demografická migrace způsobuje, že klesá podíl mladších obyvatel v produktivním věku ve stř̌edně velkých

\footnotetext{
5 McMILLAN, David W. a David M. CHAVIS. Sense of Community: A Definition and Theory. Journal of Community Psychology, 1986, roč. 14, č. 1, s. 6-23.
} 
městech, zejména na Vysočině, pomezí severozápadní Moravy a východních Čech nebo na východní Moravě, ve prospěch suburbií Prahy, Brna, Ostravy, Plzně apod. ${ }^{6}$ Mezi málo společných faktorů patř́i zvyšující se průměrný věk obyvatelstva, tj. stárnutí populace. ${ }^{7}$

S takovou znalostí lze poté přistoupit k zodpovězení zásadní otázky, s čím se konkrétně identifikuje daná komunita a co $\mathrm{v}$ ní vytváří pocit př́islušnosti. Na těchto úvahách postavili program např́íklad muzejníci z Rjazaňské oblasti. ${ }^{8}$ Regionální muzeum musí především aktivně pracovat už se samotnou sbírkou. $\mathrm{V}$ první řadě má muzealizovat specifické fenomény, předměty úzce spjaté s komunitou a jejím životem, čímž se stává pamětí věcí. V prezentaci se pak musí dostat mezi místní publikum nenásilně například pomocí „muzejních ostrůvkư", tedy rozsahem malých výstavek na frekventovaných místech komunity. $V$ případě, že $v$ oblasti existuje živoucí specifická činnost, tradičně např́íklad řemesla, regionální muzeum ji má využít k provázání s jeho prací. Vzájemné provázání lze uskutečnit i prostřednictvím přímé pomoci komunitě. Např́íklad malá muzea na severovýchodě Spojených států poskytla své budovy jako volební místnosti. Instituce se tak dostaly do širokého povědomí, což je základní předpoklad pro

\footnotetext{
6 Demografické procesy a struktura obyvatel v obcích metropolitních oblastí České republiky v letech 2012 až 2014. Specializovaná mapa. Přírodovědecká fakulta Univerzity Karlovy. In Atlas obyvatelstva. Specializovaný mapový portál [online]. 2017 [cit. 2019-05-10]. Dostupný z www: $<$ http://www.atlasobyvatelstva.cz/cs/demograficke-a-migracni-procesy $>$.

7 ŠTYGLEROVÁ, Terezie. The population development of the Czech Republic in 2008. Czech Demography, 2010, roč. 4, s. 6.

8 KAULEN, Maria, Irina CHUVILOVA a Olga CHERKAEVA. Regional Museums in Russia: How to Solve the Accessibility Problem? Museum Network Development Strategy. Museologica Brunensia, 2015, roč. 4, č. 1, s. 16-21.

9 Ibidem, s. 19
}

úspěch regionálního muzea, jak připomíná Barbara Walden. ${ }^{10}$

Regionální muzea v českém prostředí nicméně vidí zásadní překážky, proč se nemohou dostat blíže sídelní komunitě, $\mathrm{v}$ málo početném personálu, nepochopením ze strany zřizovatelů a s tím spojeného chronického podfinancování. Jak uvádí dokument AMG ČR k projektu malých muzeí, $\mathrm{v}$ regionálních institucích často dochází ke kumulaci funkcí, která si vyžaduje neúměrnou časovou náročnost. Častým argumentem je též špatný vztah, nebo obtížná komunikace, se zrrizovatelem, který se projevuje v dlouhodobém podfinancování. ${ }^{11}$ Muzea to považují za začarovaný kruh, který samotná neprorazí, a spoléhají se na vnější pomoc. Nicméně řešení spočívá pouze $v$ jejich rukou a nikoli v nějakém deus ex machina $v$ podobě zřizovatele či zastřešující organizace jako například AMG ČR.

Personální potíže se dají do určité míry vyvážit dobrovolnictvím. V českém prostředí se tato forma společenské pomoci teprve etabluje. Muzea mají v tomto směru výhodu na dobrovolnickém trhu, nebot jejich odkaz na kolektivní pamět je komunitě dobře srozumitelný. V zahraničí se ukazuje, že řada malých muzeí úspěšně stojí a padá s dobrovolnictvím. ${ }^{12}$ Právě dobrovolníci efektivně propojují komunitu s muzeem a při správném vedení rozši-

10 WALDEN, Barbara B. Like a Good Neighbor: Community Advocacy and Outreach for Small Museums. History News, 2013, roč. 68, č. 3, s. 20-21 [online]. Database JSTOR [cit. 2019-05-

-10]. Dostupný z www: <https://www.jstor.org/ stable/42654368>

11 Argumenty muzeí IV. kategorie uvádí například AMG ČR, viz Projekt „Malá muzea“ v rámc AMG. In Asociace muzeí a galerií CR [online]. [cit. 2019-05-05]. Dostupný z www: <https://www. cz-museums.cz/web/deni_v_oboru/mala-muzea/ projekt-mala-muzea $>$.

12 Ibidem, s. 21. V České republice jako vzor může sloužit Národní muzeum, byt̉ uplatnění takového modelu na regionální muzeum má pochopitelně výrazné limity. TŮMOVÁ, Ludmila. Dobrovolnický program Národního muzea v letech 2015-2017. Muzeum: Muzejní a vlastivědná práce, 2018, roč. 56, č. 1 , s. 50-55. řují jeho okruh instituce. Variantou dobrovolnictví jsou formální muzejní spolky i neoficiální sdružení práátel. Taková uskupení jsou vhodná zvlášť k hledání specifických regionálních fenoménů $\mathrm{k}$ muzealizaci, atraktivních témat i forem pro prezentace, protože mají pevné kořeny v sídelní komunitě. Efektivně využité dobrovolnictví je přímo úměrné kvalitě řízení a vedení ze strany daného regionálního muzea. Druhý směr spočívá ve spolupráci muzea s jinými místními institucemi, jako je kulturní středisko, regionální knihovna, nestátní dobrovolné spolky apod. Vzájemná koordinace a společné aktivity pomůžou tomu, aby se muzeum dostalo do povědomí komunity v pojetí Barbary Walden.

V dnešní globalizované společnosti přetrvává $\mathrm{v}$ sídelních komunitách požadavek na uchování jedinečné kolektivní paměti, což bylo a je smyslem regionálního muzea od počátku občanské společnosti. Muzea nicméně ustrnula ve formě sdílení paměti vůči současné společnosti. Ke znovunavázání smyslu v očích komunity je třeba detailní znalost samotné komunitní struktury, jejího vývoje, pocitu příslušnosti a tradic. $V$ českém prostředí se objevují argumenty, že malá muzea nemají dostatečný personál, finance i podporu ze strany zřizovatelů. Komunitní muzeum ovšem může plnit svoji funkci prostřednictvím dobrovolnické sítě a spolupráce $s$ dalšími místními nositeli kolektivní paměti. V důvodech udávaných regionálními muzei se objevuje spíše variace „cvičené neschopnosti“, tj. shromažd’ování argumentů, proč to nejde, ${ }^{13}$ než nezvratitelná fakta. Muzeum jako komunitní centrum lze totiž vybudovat jen za předpokladu, že se instituce řídí jasnou a reálnou vizí pro dané prostředí.

\footnotetext{
13 K termínu „cvičené neschopnosti“ v muzejním prostředí ŽALMAN, Jiří. Kapesní průvodce o muzeu a muzejnictví (fiktivní rozhovor Jiř́ho Z̆almana s muzejní elévkou). Praha: Národní muzeum, 2016, s. 182-183.
} 


\section{LITERATURA:}

Demografické procesy a struktura obyvatel v obcích metropolitních oblastí České republiky v letech 2012 až 2014. Specializovaná mapa. Přírodovědecká fakulta Univerzity Karlovy. In Atlas obyvatelstva. Specializovaný mapový portál [online]. 2017 [cit. 2019-05-10]. Dostupný z www: $<$ http://www.atlasobyvatelstva.cz/cs/ demograficke-a-migracni-procesy $>$.

DODD, Jocelyn. The socially purposeful museum. Museologica Brunensia, 2015, roč. 4, č. 2, s. 28-32. ISSN 1805-4722.

KAULEN, Maria, Irina CHUVILOVA a Olga CHERKAEVA. Regional Museums in Russia: How to Solve the Accessibility Problem? Museum Network Development Strategy. Museologica Brunensia, 2015, roč. 4, č. 1, s. 16-21. ISSN 1805-4722.

McMILLAN, David W. a David M. CHA-

VIS. Sense of Community: A Definition and Theory. Journal of Community

Psychology, 1986, roč. 14, č. 1, s. 6-23. ISSN 1520-6629. https://doi.org/10.1002/ 1520-6629(198601)14:1<6::AID-JCO-

P2290140103>3.0.CO;2-I
Projekt „Malá muzea“ v rámci AMG. In Asociace muzeí a galerií ČR [online]. [cit. 2019-05-05]. Dostupný z www: <https://www.cz-museums.cz/web/ deni_v_oboru/mala-muzea/projekt-malamuzea $>$.

ŠTYGLEROVÁ, Terezie. The population development of the Czech Republic in 2008. Czech Demography, 2010, roč. 4, s. 3-22.

ŠUBRT, Jiří a Štěpánka PFEIFEROVÁ. Kolektivní pamět jako předmět historickosociologického bádání. Historická sociologie, 2010, roč. 2, č. 1, s. 9-29. ISSN 1804-0616.

Take part in creating a new museum definition - the backbone of ICOM. In ICOM [online]. [cit. 2019-05-05]. Dostupný z www: <https://icom.museum/en/ activities/standards-guidelines/museumdefinition/>

TŮMOVÁ, Ludmila. Dobrovolnický program Národního muzea v letech 2015-2017. Muzeum: Muzejní a vlastivědná práce, 2018, roč. 56, č. 1, s. 50-55. ISSN 1803-0386.
WALDEN, Barbara B. Like a Good Neighbor: Community Advocacy and Outreach for Small Museums. History News, 2013, roč. 68, č. 3, s. 19-23 [online]. Database JSTOR [cit. 2019-05-10]. Dostupný z www: <https://www.jstor.org/ stable/42654368>. ISSN 0363-7492.

ŽALMAN, Jiří. Kapesní průvodce o muzeu a muzejnictví (fiktivní rozhovor Jiř́ho Žalmana s muzejní elévkou). Praha: Národní muzeum, 2016. ISBN 978-80-7036-504-5.

ŽALMAN, Jiří. Malá muzea (přednáška na semináři v Plzni). Věstník Asociace muzeí a galerií České republiky, 2007, č. 2, s. 8-10. ISSN 1213-2152.

\section{PETR BERÁNEK}

Muzeum Vysočiny Třebíč, pobočka Muzeum řemesel Moravské Budějovice; student muzeologie, Ústav archeologie a muzeologie, Filozofická fakulta, Masarykova univerzita, Brno, Česká republika 